\title{
PROGRAM SOSIALISASI PENDIDIKAN UNTUK MENINGKATKAN ANGKA HARAPAN LAMA SEKOLAH (HLS)
}

\section{EDUCATION SOCIALISZATION PROGRAM FOR INCREASING THE EXPECTED YEARS OF SCHOOLING (EYS)}

\author{
RW Wulandari'1a, A Kholik', M Qudsiyah'1, dan R Agustian'1 \\ 1Fakultas Keguruan dan Ilmu Pendidikan, Universitas Djuanda Bogor, Jl. Tol Ciawi No.1 Kotak Pos 35 \\ Bogor 16720 Indonesia \\ a Korespondensi: Ratna Wahyu Wulandari, Email: ratnawahyuwulandari@unida.ac.id
}

(Diterima: 03-01-2018; Ditelaah: 03-1-2017; Disetujui: 05-04-2018)

\begin{abstract}
Educational Socialization Program is an activity of community service in order to help Bogor Regency government to increase Expected Years of Schooling (EYS) towards formal education. This activity is in the form of a series of activities consisting of socialization of learning interest in early childhood, 12-year compulsory socialization, procurement of reading park, and learning guidance activities. The purpose of this activity are (1) to increase public interest in early childhood; (2) to increase public interest in formal education; (3) to increase literacy of knowledge by reading; and (4) to increase the activity of learners in the field of education. There are several steps taken to carry out this devotional activity, they are (1) situation analysis, is the activities undertaken to collect data of observation and mapping problems; (2) the design of activities, carried out after the problems are identified and mapped and then formulate appropriate solutions to be applied; and (3) the implementation of activities, carried out in accordance with the plans that have been prepared. This socialization provides an impact to the community in the form of educational motivation and community empowerment activities.
\end{abstract}

Keywords: educational socialization program, expected years of schooling, formal education, community empowerment activities.

\begin{abstract}
ABSTRAK
Program Sosialisasi Pendidikan merupakan kegiatan pengabdian kepada masyarakat dalam rangka membantu pemerintah Kabupaten Bogor untuk meningkatkan Angka Harapan Lama Sekolah (HLS) anak-anak terhadap pendidikan formal. Kegiatan ini berbentuk serangkaian kegiatan yang terdiri dari sosialisasi minat belajar di PAUD, sosialisasi wajib belajar 12 tahun, pengadaan taman baca, dan kegiatan bimbingan belajar. Tujuan dari kegiatan ini antara lain (1) meningkatkan minat masyarakat terhadap PAUD; (2) meningkatkan minat masyarakat terhadap pendidikan formal; (3) meningkatkan literasi pengetahuan dengan membaca; dan (4) meningkatkan aktivitas peserta didik di bidang pendidikan. Ada beberapa langkah yang dilakukan untuk melaksanakan kegiatan pengabdian ini, yaitu (1) analisis situasi, adalah kegiatan yang dilakukan untuk mengumpulkan data hasil observasi serta melakukan pemetaan permasalahan; (2) perancangan kegiatan, dilakukan setelah permasalahan diketahui dan dipetakan kemudian merumuskan solusi tepat yang akan diterapkan; dan (3) pengimplementasian kegiatan, dilakukan sesuai dengan rencana yang telah disusun. Sosialisasi ini memberikan dampak kepada masyarakat dalam bentuk motivasi pendidikan dan aktivitas pemberdayaan masyarakat.
\end{abstract}


Kata kunci: program sosialisasi pendidikan, nilai harapan sekolah, pendidikan formal, pemberdayaan masyarakat.

Wulandari R. W., Kholik, A., Qudsiyah, M., \& Agustian, R. (2018). Program Sosialisasi Pendidikan untuk Meningkatkan Angka Harapan Lama Sekolah (HLS). Qardhul Hasan: Media Pengabdian kepada Masyarakat 4(1): 48-64.

\section{PENDAHULUAN}

Pendidikan merupakan alat dalam membangun manusia yang tidak hanya cerdas tapi juga berkualitas, dan sangat mendorong pertumbuhan ekonomi, sosial, budaya, dan politik untuk kemajuan suatu daerah. Pendidikan juga dapat menumbuhkembangkan keterlibatan seorang siswa dalam bermasyarakat, tidak hanya pada tingkat lokal tapi juga tingkat global (Tilaar, 1999). Dalam teori maupun konsep pembangunan, suatu daerah itu dapat dikatakan maju apabila pendidikannya baik dan memiliki Sumber Daya Manusia (SDM) yang berkualitas sehingga memiliki kemampuan untuk bersaing dengan daerah yang lain.

Pada Pasal 24 (ayat 2) undang-undang Sisdiknas dijelaskan, perguruan tinggi mempunyai wewenang untuk mengatur lembaganya dalam bidang penyelenggaraan pendidikan, pelaksanaan penelitian ilmiah oleh dosen, serta pelaksanaan pengabdian dosen dan mahasiswanya kepada masyarakat. Ketiga komponen tersebut disebut tri darma perguruan tinggi yaitu yang pelaksanaannya harus dijalankan secara seimbang sehingga menghasilkan lulusan yang berkompeten dan memiliki bekal pengetahuan yang mumpuni, mampu melakukan penelitian, dan melaksanakan pengabdian demi kesejahteraan masyarakat sekitarnya. Cara yang digunakan dalam menerapkan tri darma perguruan tinggi dilakukan dengan melaksanakan segala upaya yang berkaitan dengan pengabdian kepada masyarakat. Kegiatan ini dilakukan civitas akademika yang terdiri dari dosen sebagai ketua pengabdi dan mahasiswa sebagai anggota tim.
Suatu kegiatan yang saat ini menjadi perhatian dari Pemerintah Kabupaten Bogor adalah kegiatan pengabdian. Berdasarkan hasil wawancara dengan Kepala Bidang Penelitian dan Pengembangan Daerah (BAPPEDA) Kabupaten Bogor diperoleh informasi bahwa Keaksaraan Fungsional (KF) yang sebelumnya sempat menjadi prioritas permasalahan yang harus diperbaiki sekarang bergeser menjadi bagaimana meningkatkan angka Harapan Lama Sekolah (HLS) masyarakat. HLS merupakan lamanya sekolah yang dihitung dalam tahun yang diharapkan ditempuh seseorang pada umur yang ditentukan. HLS digunakan untuk memantau tingkat pembangunan sistem pendidikan yang diterapkan di berbagai jenjang dihitung mulai pada usia tujuh tahun. Pemilihan umur tujuh tahun didasarkan pada program wajib belajar yang penyelenggaraannya diatur oleh pemerintah (BPS Jabar, 2015).

Menurunnya angka HLS Kabupaten Bogor terjadi karena dua faktor diantaranya adalah permasalahan ekonomi dan motivasi keluarga. Masyarakat dengan perekonomian menengah ke bawah cenderung memiliki minat terhadap pendidikan yang rendah. Biaya transportasi dan biaya peralatan sekolah dianggap masih terlalu tinggi untuk diwujudkan. Selain itu tingkat kepercayaan terhadap lembaga pendidikan juga mempengaruhi motivasi orang tua untuk menyekolahkan anaknya, terutama untuk jenjang pendidikan yang lebih tinggi. Dua hal tersebut berkolaborasi menjadi sebuah siklus, perekonamian yang masih rendah ditambah dengan kurangnya motivasi belajar dari keluarga sehingga orang tua menginginkan anaknya bekerja lebih dini, inilah yang mengakibatkan menurunnya angka HLS. 
Data BPS (2016) menunjukkan, Kabupaten Bogor menduduki peringkat 15 di daerah Jawa Barat dilihat dari nilai IPM (Indeks Pembangunan Masyarakat). Dimana penilaian IPM ini dihasilkan dari pengukuran angka harapan hidup, standar hidup layak, dan HLS masyarakat. Dengan melihat hasil tersebut, setiap daerah berupaya meningkatkan nilai IPM dengan tujuan supaya tidak ketinggalan dari daerah lain dan dapat menjadi daerah yang mampu bersaing. Sehingga perlu adanya upaya meningkatkan nilai IPM melalui peningkatan angka harapan hidup, standar hidup layak, dan HLS masyarakat. Salah satu usaha peningkatan nilai IPM adalah melalui peningkatan angka HLS. Upaya tersebut dilakukan dengan memberikan programprogram dan sosialisasi yang terintegrasi.

Daerah yang menjadi target dalam melaksanakan kegiatan pengabdian ini adalah Desa Sadeng, Kecamatan Leuwisadeng, Kabupaten Bogor. Desa Sadeng dipilih karena berdasarkan letaknya, Desa Sadeng masih memiliki desa yang jauh dari fasilitas perkotaan, dan minat terhadap pendidikan formal masih sangat rendah. Perlu adanya motivasi dalam menumbuhkan minat masyarakat terhadap pendidikan, sehingga angka HLS dapat ditingkatkan.

Angka HLS ditingkatkan dengan mengintegrasikan beberapa kegiatan sosialisasi pendidikan. Kegiatan tersebut terdiri dari, (1) sosialisasi minat belajar di PAUD, (2) sosialisasi wajib belajar 12 tahun, (3) pengadaan tamanbaca, dan (4) kegiatan bimbingan belajar. Keempat kegiatan tersebut tidak hanya membutuhkan peran serta peserta didik, tapi juga melibatkan orang tua secara langsung. Tujuan khusus kegiatan ini adalah, (1) meningkatkan minat belajar di PAUD, (2) meningkatkan minat belajar di lembaga pendidikan formal, (3) meningkatkan literasi pengetahuan dengan membaca, dan (4) meningkatkan peran serta peserta didik di bidang pendidikan. Sedangkan tujuan umumnya yaitu untuk mengoptimalkan kegiatan masyarakat di bidang lainnya.

\section{MATERI DAN METODE}

\section{Materi}

\section{Harapan Lama Sekolah (HLS)}

Indeks Pembangunan Manusia (IPM) digunakan untuk menentukan sebuah negara termasuk ke dalam kriteria negara maju atau berkembang. Indeks ini ditentukan oleh beberapa dimensi, diantaranya (1) panjangnya umur dan hidup sehat, ditentukan berdasarkan angka harapan hidup saat kelahiran; (2) pengetahuan masyarakat, ditentukan berdasarkan angka HLS; (3) standar hidup layak, ditentukan berdasarkan Produk Domestik Bruto (PDB) yang menunjukkan keseimbangan berbelanja yang diukur per kapita (BPS, 2016). Menurut Badan Pusat Statistik (BPS), IPM mempunyai beberapa manfaat, (1) IPM sebagai indikator dalam pengukuran kualitas hidup manusia; (2) IPM digunakan untuk menentukan peringkat pembangunan wilayah atau negara; (3) bagi Indonesia IPM dapat digunakan sebagai data setrategis untuk mengukur kinerja pemerintah dan salah satu penentu Dana Alokasi Umum (DAU). Saat ini IPM Kabupaten Bogor berada di peringkat 15 dari 27 kota di Jawa Barat dengan nilai IPM 68,32, dimana kabupaten atau kota dengan IPM tertinggi diperoleh Kota Bandung dengan nilai 80,13 (BPS Jabar, 2015).

HLS merupakan lamanya menempuh sekolah yang dihitung dalam tahun yang yang ditempuh oleh anak umur tertentu. HLS menjadi satu dari beberapa komponen dalam menentukan IPM, dan menentukan kondisi sistem pendidikan yang sedang dibangun di berbagai jenjang mulai pada usia tujuh tahun (BPS, 2016). Dibutuhkan sosialisasi pendidikan untuk memberikan motivasi dan dorongan bagi anak-anak agar tetap bisa merasa tertarik dengan pendidikan yang sedang dijalaninya, terutama dalam hal ini pendidikan pada tinkat PAUD dan wajib belajar 12 tahun, 
sehingga mereka selalu memiliki keinginan untuk melanjutkan pendidikan ke jenjang berikutnya.

Berdasarkan penelitian tentang pengaruh rata-rata HLS terhadap Produk Domestik Regional Bruto (PDRB) per kapita menyimpulkan bahwa hasil analisis lama sekolah menghasilkan rata-rata yang signifikan dan memiliki pengaruh positif terhadap PDRB yang dihitung per kapita. Sehingga semakin tinggi HLS di suatu daerah mengakibatkan semakin tingginya PDRB per kapita (Handayani, Bendesa, \& Yuliarmi, 2016). Program sosialisasi pendidikan, yang dalam hal ini terdiri dari sosialisasi PAUD dan wajib belajar 12 tahun pada pendidikan formal dianggap mampu meningkatkan HLS suatu daerah. Hal ini memberikan dampak positif terhadap pengetahuan, pengalaman, dan kreativitas masyarakat, sehingga seiring dengan meningkatnya angka HLS maka angka PDRB per kapita juga dapat ditingkatkan.

\section{Sosialisasi Pendidikan}

Kegiatan sosialisasi memiliki proses utama berupa kegiatan mentransfer kebiasaan, nilai, dan peraturan antar generasi dalam suatu masyarakat. Sosialisasi disebut juga sebagai teori peranan (role theory), dimana di dalamnya mengajarkan peranan individu yang harus dilakukan. Sosialisasi memiliki dua jenis yaitu, (1) sosialisasi primer, terjadi dalam keluarga; dan (2) sosialisasi sekunder, terjadi dalam masyarakat. Kedua sosialisasi tersebut memiliki beberapa kesamaan yaitu, (1) terjadi di tempat bekerja dan tempat tinggal yang keduanya disebut institusi total; (2) melibatkan beberapa individu dalam satu situasi; (3) terpisah dari kelompok masyarakat dalam waktu yang telah ditentukan; (4) hidup dijalani dalam kungkungan; dan (5) memiliki peraturan yang formal (Kun, 2005).

Sosialisasi primer dialami oleh individu ketika berada pada masa kecil. Hal ini diwujudkan dengan selalu belajar untuk menjadi anggota dari suatu masyarakat, yaitu keluarga. Kegiatan ini berlangsung pada anak yang berusia 1-5 tahun sebelum memasuki sekolah dasar. Pada awal pertumbuhan, seorang anak hanya mengenal anggota keluarga beserta lingkungan yang berada dekat dengan keluarganya. Secara bertahap seorang anak mampu mengenali dan membedakan orang lain di luar keluarganya. Pada masa ini, orang yang pertama dikenal di dalam keluarga menjadi orang paling penting dalam menumbuhkan pola interaksi terbatas. Dari hasil interaksi terbatas ini terbentuklah warna kepribadian seorang anak.

Sosialisasi lanjutan yang dianggap sebagai proses yang dijalani setelah sosialisasi primer disebut sosialisasi skunder. Sosialisasi skunder memberikan sebuah pengalaman kepada individu untuk mengenal kelompok lain dalam suatu masyarakat. Kegiatannya berupa resosialisasi dan desosialisasi. Resosialisasi adalah identitas diri yang diberikan berbeda dari sebelumnya, desosialisasi adalah pencabutan identitas lama.

Berdasarkan perbedaan standar dan nilainya, tipe sosialisasi dibedakan atas sosialisasi formal dan informal. Kedua sosialisasi ini memiliki pengaruh besar terhadap pertumbuhan kepribadian anak sehingga anak akan bertingkah laku sesuai dengan norma yang ada dalam lingkungannya. Hasil dari kedua sosialisasi sangat susah untuk dibedakan, karena sosialisasi formal dan informal sering kali hadir secara bersama pada suatu kegiatan. Sosialisasi formal, berada di lembagalembaga resmi dengan wewenang sesuai dengan aturan negara, misalnya pendidikan yang dilakukan di sekolah dan pendidikan yang dilakukan di militer. Sedangkan sosialisasi informal merupakan kegiatan yang dianggap sebagai tempat bergaul secara kekeluargaan, seperti interaksi yang terjadi antar teman atau sesama anggota dalam masyarakat sosial (Narwoko \& Suyanto, 2006).

Sekolah sebagai lingkungan formal merupakan tempat yang baik bagi anak untuk bergaul dengan komponen sekolah, 
yaitu teman sebaya, guru, dan karyawan sekolah. Dalam pergaulan tersebut seorang anak mendapatkan pengalaman dalam proses bersosialisasi sehingga mereka mengetahui peran mereka dalam lingkungan sekitar dan tindakan apa saja yang harus diambil dalam kondisi tertentu. Melalui proses tersebut diharapkan seorang anak mampu menilai dirinya secara manndiri.

Menurut Narwoko dan Suyanto (2006), tujuan sosialisasi antara lain, (1) Memberikan bekal keterampilan kepada masyarakat untuk diterapkan ke lingkup yang lebih luas. Sosialisasi yang diberikan kepada individu dapat digunakan modal dasar untuk belajar bersosialisasi sehingga mudah diterima dalam lingkungan bermasyarakat; (2) Meningkatkan kemampuan berkomunikasi individu. Sosialisasi dapat membuat seseorang bertukar informasi dengan orang lain, bahkan dengan orang baru sekalipun, hal ini sekaligus dapat meningkatkan rasa percaya diri seseorang; (3) Mengembangkan kejiwaan seseorang sehingga mampu untuk mengevaluasi diri dengan tepat. Dengan kemampuan mengevaluasi diri yang dimiliki seorang individu menjadikan individu tersebut untuk memperbaiki kelemahankelemahan psikologi yang dimilikinya selama bergaul dengan masyarakat; (4) Menyerap nilai-nilai positif yang ada di lingkungan masyarakat. Seorang individu dapat melatih kemampuannya dengan cara mengadopsi maupun mengadaptasi kemampuan orang lain, sehingga seseorang akan lebih percaya diri dalam bergaul.

Berdasarkan konsekuensi yang diberikan, sosialisasi dibedakan atas sosialisasi represif dan sosialisasi partisipatoris. Sosialisasi represif atau repressive socialization menggunakan hukuman sebagai konsekuensinya, yaitu bisa berupa materi atau imbalan. Contoh kejadian dalam masyarakat yang menggambarkan sosialisasi represif adalah kepatuhan anak terhadap orang tua, dimana komunikasi terjadi satu arah dan berisi perintah-perintah, orang tua berperan sebagai pemberi sosialisasi dan keluarga berperan sebagai significant other. Sedangkan sosialisasi partisipatoris atau participatory socialization lebih memfokuskan pada pemberian imbalan saat berperilaku baik, dimana imbalannya bersifat simbolik, dan anak diberi kebebasan sehingga dapat dikatakan bahwa anak dan keperluannya sebagai pusat sosialisasi sedangkan keluarga berperan sebagai generalized other.

Menurut George Herbert Mead, penerapan sosialisasi pada seseorang memiliki tahapan-tahapan berikut: (1) Tahap persiapan (preparatory stage), tahap dimana seseorang mulai mengenal sosialisasi yaitu ketika individu baru saja lahir, dan mulai mencari pemahaman diri. Pada tahapan ini seorang individu sering melakukan kegiatan peniruan yang awalnya tidak sempurna tetapi akan sempurna seiring berjalannya waktu. Contohnya, ketika seorang ibu mengajarkan pengucapan kata "makan" yang awalnya tidak dipahami artinya oleh seorang anak, lama-kelamaan anak tersebut memahami artinya melalui pengalaman yang telah dilaluinya; (2) Tahap meniru (play stage), ditandai dengan perilaku seorang anak yang mulai mahir menduplikasi orang dewasa. Seorang anak mulai mengenal dirinya sendiri, orang tuanya, dan keluarganya yang lain. Selain itu seorang anak juga mulai memahami harapan orang tuanya, dan mulai bisa menempatkan diri dan memikirkan berada di posisi orang lain. Ini akan semakin memperkuat pikiran seorang anak bahwa kehidupan sosial berisikan orang-orang yang memiliki kepribadian yang berbeda-beda. Sebagian dari orangorang tersebut merupakan bagian terpenting dalam pembentukan kepribadian dan pertahanan diri, yaitu adanya proses penyerapan nilai dan norma dari orang yang dianggapnya berarti (significant other); (3) Tahap siap bertindak (game stage), memperlihatkan telah berkurangnya proses peniruan dan berubah menjadi proses pengambilan peran yang langsung diambil alih dengan penuh kesadaran. Pada tahap 
ini kemampuan menempatkan diri sebagai orang lain mulai meningkat. Seorang anak mulai mengerti keharusan dalam membela keluarga dan bekerjasama dengan teman sebaya. Peraturan dan norma yang diterapkan dalam keluarga mulai dimengerti, demikian pula yang ada di luar keluarganya. Lawan berinteraksi semakin lama semakin banyak dan kompleks; (4) Tahap penerimaan norma kolektif (generalize stage/generalized other), seseorang sudah dianggap dewasa. Individu pada tahap ini telah mampu menentukan posisi diantara masyarakat luas. Peraturanperaturan yang diterapkan dalam lingkungannya dapat dihormati, tidak hanya di lingkungan sekitarnya, tetapi juga lingkungan luar yang dianggapnya mulai penting untuk dihormati secara mantap. Sehingga dapat disebut sebagai bagian dari warga masyarakat secara penuh.

Menurut Charles H. Cooley, manusia dibentuk berdasarkan interaksi yang dialaminya. Proses interaksi ini dibagi menjadi beberapa tahapan, yaitu: (1) Membayangkan kepribadian diri sendiri, misalnya seseorang merasa bahwa dirinya merasa lebih hebat dibandingkan dengan orang lain; (2) Membayangkan kepribadian diri sendiri di mata orang lain, misalnya bahwa orang lain memiliki penilain yang bermacam-macam dan berbeda-beda, baik penilaian yang positif maupun yang negatif; (3) Membayangkan perasaan diri sendiri sebagai akibat dari penilain orang lain, sehingga timbul rasa percaya diri. Ketiganya merupakan tahapan teori labeling dimana seseorang akan berperilaku berdasarkan penilaian orang lain terhadapnya. Misalnya, seorang anak yang diberi label "nakal" akan berperilaku "nakal" seperti yang dilabelkannya, walaupun hal itu belum tentu sesuai dengan kenyataannya.

Yang selanjutnya adalah agen sosialisasi, yang merupakan pihak-pihak yang menjalankan kegiatan sosialisasi. Yang termasuk empat agen sosialisasi utama adalah keluarga, media massa, kelompok bermain, dan lembaga pendidikan di sekolah. Misi yang dibawa oleh agen sosialisasipun berbeda0-beda, dan tidak selalu sejalan dan dipengaruhi oleh situasi konflik pribadi. Lebih baik jika agen sosialisasi dapat berjalan beriringan, tidak bertentangan, dan saling mendukung.

Agen lain yang juga terlibat dalam proses sosialisasi adalah institusi agama, organisasi rekreasional, tetangga, masyarakat, dan lingkungan pekerjaan. Agen-agen sosialisasi ini akan membantu seseorang dalam membangun banyak persepsi tentang dunianya sendiri yang berkaitan dengan pantas dan tidak pantasnya sesuatu untuk dilakukan. Ada beberapa kasus, agen-agen tersebut memilki pengaruh yang sangat besar.

\section{Pendidikan Formal}

Undang-undang nomor 20 tahun 2003 menjelaskan bahwa Indonesia memiliki tiga jalur pendidikan, yaitu formal, non-formal, dan informal. Pendidikan yang kegiatannya dilaksanakan secara teratur, bertingkat, sistematis, dan memiliki syarat-syarat yang jelas merupakan ciri dari pendidikan formal. Menurut undang-undang sisdiknas tersebut juga bahwa sekolah merupakan bagian dari pendidikan formal yang memiliki jenjang dan berkesinambungan. Sekolah adalah contoh pendidikan formal berbentuk lembaga. Sekolah dikembangkan oleh masyarakat sebagai wujud dari kewajibannya dalam memberikan pelayanannya dalam mendidik generasi muda.

Menurut undang-undang tentang sisdiknas, pendidikan formal terdiri dari pendidikan dasar, pendidikan menengah, dan pendidikan tinggi. Secara baku pendidikan ini terdiri dari SD, SMP, SMA, dan Perguruan Tinggi. Fokus dari pendidikan ini adalah pemberian keteladanan, memunculkan kemauan, dan membentuk siswa yang kreatif.

Lembaga pendidikan formal dapat digunakan sebagai sarana untuk menghasilkan generasi cerdas dan kompetitif (Nofijantie, 2014). Lembaga pendidikan formal digunakan sebagai wadah dalam menerapkan pendidikan 
karakter. Dalam hal ini guru memiliki tugas membentuk sikap dan perilaku siswa sehingga mampu menjadi agents of madernization tidak hanya bagi dirinya sendiri tetapi juga bagi lingkungan bermasyarakat. Proses pembelajaran yang difasilitasi oleh guru akan membantu siswa menjadi pribadi yang berbudaya tinggi dan bernilai tinggi, yaitu pribadi yang bermoral, berwatak, bertanggung jawab, dan bersosialisasi, sehingga label cerdas dan kompetitifpun dapat dengan mudah diraih oleh siswa.

Menurut Mudyahardjo (2002) Sekolah sebagai lembaga pendidikan formal memiliki fungsi yaitu: 1) Memberikan pelatihan guna meningkatkan kemampuan akademis anak; 2) Memperkuat mental dan tingkat kedisiplinan; 3) Melatih siswa memiliki rasa tanggung jawab; 4) Menumbuhkan jiwa sosial dan memperluas jaringan pertemanan; 5) Memperkuat identitas diri; dan 6) Sebagai tempat memngembangkan keatifitas anak.

Dalam pendidikan formal siswa dihadapkan pada proses pendidikan yang memiliki karakteristik, yaitu penyelengaraannya dilakukan secara khusus yang jenjangnya memiliki hubungan hierarki, usia anak didik bersifat homogen, pendidikan dilakukan dalam jangka waktu yang relatif lama sesuai dengan program yang telah disusun, memberikan materi pendidikan yang bersifat akademis dan umum, memberikan penekanan bahwa pendidikan merupakan kebutuhan bagi kehidupan di masa mendatang (Oemar, 2005). Dengan adanya karakteristik tersebut, keberadaan pendidikan formal akan lebih berarti bagi siswa. Siswa lebih menghargai proses pendidikan dan berlomba-lomba untuk mendapatkan hasil yang terbaik.

\section{Pendidikan Anak Usia Dini (PAUD)}

PAUD merupakan jenjang pendidikan yang paling dasar dari upaya pembinaan bagi anak-anak sejak lahir hingga mencapai usia enam tahun (Hasan, 2012). Dalam kegiatannya, anak-anak diberi rangsangan pendidikan guna membantu perkembangan dan pertumbuhan jasmani dan rohani sehingga seorang anak siap memasuki pendidikan selanjutnya. PAUD biasanya diselenggarakan secara formal, nonformal, dan informal. Penyelenggaraan PAUD menitikberatkan pada lima perkembangan, yaitu perkembangan moral-agama, fisik (koordinasi motorik kasar dan halus), kecerdasan (daya pikir dan daya cipta), sosioemosional (sikap dan emosi), dan bahasa-komunikasi. Kelima tahapan disesuaikan dengan perkembangan anak pada usia-usia tertentu.

Menurut UU Sisdiknas Pasal 28 No. 20 tahun 2003, rentang usia anak usia dini adalah 0 sampai 6 tahun. Sedangkan berdasarkan rumpun keilmuan PAUD, PAUD dimulai sejak 0 tahun sampai 8 tahun atau yang biasa disebut masa emas anak, hal ini juga telah diselenggarakan di beberapa negara,. PAUD diselenggarakan dengan tujuan utama dan penyerta. Tujuan utamanya adalah membentuk kualitas anak, anak-anak dapat berkembang dan tumbuh sesuai tingkat perkembangannya untuk dapat seoptimal mungkin memasuki pendidikan dasar dan menghadapi masa depannya ketika dewasa. Sedangkan tujuan penyertanya adalah membantu menyiapkan anak-anak dalam mengoptimalkan kesiapan belajar secara akademik di sekolah, sehigga dapat mengurangi angka putus sekolah dan dapat bersaing dalam pendidikan.

Beberapa penelitian mutakhir yang menunjukkan manfaat PAUD terhadap tumbuh kembang anak diantaranya adalah Soegeng (2006) yang mengatakan bahwa pendidikan anak usia dini memiliki misi untuk mengembangkan potensi anak sesuai dengan periode tumbuh kembang anak akan menghasilkan anak yang cerdas dan berkarakter. Selain itu juga, ciri anak usia 0 sampai 6 tahun yang sehat adalah yang bersemangat bermain dan berinteraksi, dan melalui PAUD sebagai wadahnya sehingga kebutuhan fasilitas untuk bermain serta berinteraksi bisa terpenuhi.

Sulisetyowati (2016) juga melakukan sebuah penelitian untuk mengetahui 
perbedaan tumbuh kembang antara anak yang menempuh pendidikan PAUD dan tanpa menempuh pendidikan PAUD. Dan hasilnya menunjukkan, bahwa anak yang menempuh pendidikan PAUD memiliki kecenderungan tumbuh kembang berdasarkan Kuesioner Pra Skrining perkembangan Anak (KPSP) sebesar 3,3 kali lebih besar daripada anak yang tidak menempuh pendidikan PAUD. Kasus ketidaksesuaian antara perkembangan anak dengan usianya lebih banyak dialami oleh anak yang tidak mengikuti posyandu terintegrasi dengan PAUD.

Pencapaian tumbuh kembang anak tak pernah lepas dengan stimulasi yang tersedia di lingkungan anak. Sesuai dengan keberadaannya, PAUD merupakan lingkungan yang secara terstruktur direkayasa agar menjadi lingkungan bermain anak sekaligus sebagai tempat belajar. Kurikulum dan metode yang digunakan memungkinkan anak mendapatkan beragam stimulasi yang mendukung aspek tumbuh kembangnya.

\section{Wajib Belajar 12 Tahun}

Menurut Undang-Undang No. 20 Tahun 2003 tentang sisdiknas, wajib belajar dinilai sebagai program pendidikan minimal yang harus ditempuh warga negara Indonesia sebagai rasa tanggung jawab pemerintah. Program wajib belajar 12 tahun menjadi kewajiban setiap orang yang merupakan warga negara yang menamatkan jenjang SMP atau sederajat pada batas usia 16 tahun sampai 18 tahun untuk menempuh pendidikan jenjang SMA atau sederajat hingga tamat.

Sebuah penelitian tentang wajib belajar 9 tahun yang dilaksanakan di Kabupaten Kediri ditemukan bahwa faktor penghambat (masuk dalam kualifikasi sangat bermasalah) terlaksananya program wajib belajar adalah: 1) faktor ekonomi, yang termasuk di dalamnya adalah mahalnya biaya sekolah, rendahnya pendapatan, dan anak membantu pekerjaan orang tua; 2) faktor geografis, yaitu berhubungan dengan jarak tempat tinggal ke sekolah yang relatif jauh, mahalnya biaya transportasi, dan luasnya wilayah pegunungan yang sulit dijangkau dengan menggunakan sepeda atau jalan kaki; 3) faktor sosial-budaya, rendahnya dukungan orang tua, rendahnya pendidikan orang tua sehingga mengakibatkan kurangnya motivasi terhadap anak; 4) faktor kelembagaan, jumlah sekolah yang belum memadai, dan kurangnya sosialisasi dari pemangku kebijakan tentang wajib belajar (Ulfatin, Mukhadis, \& Imron, 2010). Pada penelitian yang sama, ditawarkan beberapa solusi untuk menuntaskan permasalahan wajib belajar, yaitu: 1) mendirikan sekolah berasrama; 2) mendirikan (menambah) sekolah baru; 3) perluasan sekolah satu atap; dan 4) mengefektifkan Kejar Paket B.

Berdasarkan penelitian yang dilakukan oleh Wardani (2013) program wajib belajar 12 tahun dapat terlaksana dengan baik apabila memperhatikan hal-hal berikut: 1) memahami tujuan kebijakan yang diimplementasikan; 2) menjalin hubungan dengan lembaga lainnya; dan 3) menyampaikan informasi kepada kelompok sasaran. Program wajib belajar merupakan program yang sangat baik untuk terus di implemantasikan. Hal tersebut dikarenakan program ini memberikan kesempatan pendidikan seluas-luasnya kepada peserta didik usia 16- 18 tahun untuk dapat mengenyam pendidikan di tingkat SMA, SMK, maupun MA. Yang nantinya hal tersebut membantu untuk meningkatkan angka APK (Angka Partisipasi Kasar), APM (Angka Partisipasi Murni), dan menurunkan angka putus sekolah.

\section{Metode}

Beberapa langkah dalam pelaksanaan kegiatan pengabdian ini, yaitu (1) analisis situasi, adalah kegiatan pengumpulan data observasi serta melakukan pemetaan permasalahan; (2) perancangan kegiatan, dilakukan setelah permasalahan diketahui dan dipetakan kemudian merumuskan solusi tepat yang akan diterapkan; dan (3) pengimplementasian kegiatan, dilaksanakan sesuai rencana yang telah disusun. 


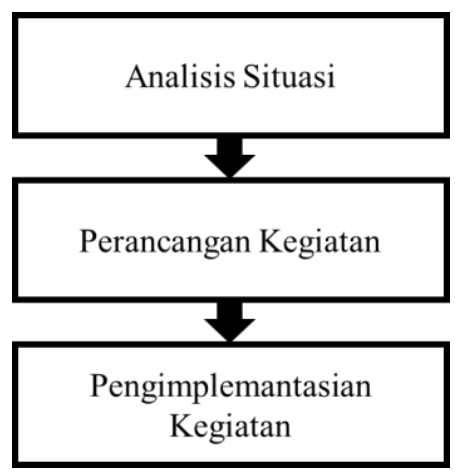

Gambar 1 Metode kegiatan pengabdian program sosialisasi

\section{Analisis Situasi}

Kampung cikadu adalah salah satu kampung yang berada di Desa Sadeng, Kecamatan Leuwisadeng, Kabupaten Bogor. Desa ini berada di ketinggian 228 meter dari permukaan laut, dengan curah hujan $2500-$ $3000 \mathrm{~mm} /$ thn dan dengan suhu $25^{\circ} \mathrm{C}-30^{\circ} \mathrm{C}$. Jumlah penduduk Desa Sadeng secara keseluruhan berjumlah 10.805 jiwa yang dirinci pada Tabel 1.

Tabel 1 Penduduk Desa Sadeng berdasarkan jenis kelamin

\begin{tabular}{lc}
\hline \multicolumn{1}{c}{ Jenis Kelamin } & Jumlah (Jiwa) \\
\hline Laki-laki & 5.827 \\
Perempuan & 4.978 \\
\hline
\end{tabular}

Sebagian besar penduduk Desa Sadeng bekerja sebagai petani dan pedagang. Jumlah profesinya ada pada Tabel 2.

Tabel 2 Mata pencaharian penduduk Desa Sadeng

\begin{tabular}{lc}
\hline \multicolumn{1}{c}{ Profesi } & Jumlah (Jiwa) \\
\hline Petani & 200 \\
Pedagang & 250 \\
Lain-lain & 9905 \\
\hline
\end{tabular}

Fasilitas pendidikan di Desa Sadeng sudah sangat memadai, walaupun jumlah dan pelayanannya masih harus terus ditingkatkan. Tersedia fasilitas pendidikan mulai dari tingkat PAUD sampai dengan SMA/MA yang sebarannya disajikan pada Tabel 3.
Tabel 3 Fasilitas pendidikan Desa Sadeng

\begin{tabular}{lc}
\hline \multicolumn{1}{c}{ Tingkat Pendidikan } & Jumah (Buah) \\
\hline PAUD & 4 \\
TK & 2 \\
SD & 7 \\
SMP/MTs & 3 \\
SMA/MA & 3 \\
\hline
\end{tabular}

Agama yang dianut masyarakat Desa Sadeng mayoritas beragama Islam. Desa ini terkenal dengan kerohanianya yang kuat, dengan adanya bukti banyaknya pondok pesantren, dan kekompakanya dalam kegiatan-kegiatan kerohaniannya. Desa Sadeng tergolong cukup maju, dari segi pendidikan, ekonomi, dan lain-lainya. Dari jumlah 6 RW yang ada terdapat beberapa kampung yang memang masih tertinggal dari segi kesadaran tentang pendidikan, ekonomi dan lain-lainya, terutama di kampung Cikadu.

Belum ada data yang tersedia di pemerintahan Desa Sadeng yang menunjukan secara kuantitatif berapa jumlah masyarakat Kampung Cikadu yang bekerja di luar desa. Sebagian besar dari pemuda Kampung Cikadu mencoba untuk mencari "modal di perantauan untuk memperbaiki taraf perekonomian masyarakat.

Kebudayaan masyarakat Desa Sadeng memang tidak dapat ditunjukkan secara khusus. Karena tidak ada sesuatu hal yang spesifik dari masyarakat setempat. Berdasarkan hasil observasi diperoleh informasi dari masyarakat setempat, masih ada beberapa kesenian yang masih lestari dan diselenggarakan secara berkesinambungan sehingga menjadi tradisi masyarakat setempat. Seperti di kampung Cikadu, setiap ada acara Maulid Nabi dan Tahun Baru Islam masyarakat melakukan sebuah tradisi yang disebut ngameng atau ngariung (berkumpul di lapangan). Selain tradisi-tradisi tersebut, masih pula dilakukan pengajian-pengajian rutin di kalangan bapak-bapak, ibu-ibu, bahkan anak-anak. Kegiatan tersebut tidak hanya dilakukan di Kampung Cikadu melainkan di 
setiap kampung yang berada di Desa Sadeng.

Sistem pemerintahan di Desa Sadeng Kecamatan Leuwisadeng, Kabupaten Bogor, berlangsung dengan baik, karena adanya kerja sama dan koordinasi antar pihak aparatur Desa Sadeng dan masyarakat setempat. Pembangunan Desa Sadeng tidak terlepas dari adanya peran masyarakat, pemerintah dan juga pemuda-pemudi yang selalu membantu peningkatkan pembangunan Desa Sadeng. Dengan adanya sekumpulan para pemuda dan pemudi di Desa Sadeng yang tergabung dalam Karang Taruna Desa Sadeng maka terciptalah inovasi-inovasi kegiatan. Selain itu dukungan penuh Kepala Desa membuat Desa Sadeng lebih berkembang

\section{Rancangan dan Implemantasi Kegiatan}

Kegiatan ini mencakup empat kegiatan utama dan beberapa kegiatan pendamping. Kegiatan utama ini terdiri dari kegiatankegiatan yang mendukung program sosialisasi pendidikan, kegiatan tersebut diantaranya, (1) sosialisasi minat belajar di PAUD, (2) sosialisasi wajib belajar 12 tahun, (3) pembentukan taman baca, dan (4) kegiatan bimbingan belajar.

\section{Sosialisasi Minat Belajar di PAUD}

Sosialisasi Minat Belajar di PAUD sebagai jenjang pendidikan sebelum sekolah dasar memiliki peranan penting dalam pembangunan pondasi pendidikan dasar seorang anak. Menurut Santrock (2014), pada tahapan anak usia dini, anak-anak akan melatih diri mereka untuk lebih mandiri, dan menyiapkan sekolah dasar mereka dengan mengembangkan keterampilan seperti belajar mengikuti instruksi dan mengidentifikasi huruf, serta menghabiskan waktu berjam-jam dengan teman sebaya mereka. Dengan alasan tersebut perlu adanya pengetahuan dari orang tua supaya memberikan kesempatan kepada anaknya untuk bersosialisasi dan melatih diri di PAUD.
Sehingga diadakan sebuah kegiatan untuk memfasilitasi sosialisasi tersebut. Sosialisasi dilaksanakan di ruang kelas PAUD Al-Hidayah. Kegiatan dilaksanakan pada Hari Kamis tanggal 10 Agustus 2017 pukul 08.00 sampai dengan pukul 10.00 WIB dengan mengundang pemateri yang ahli di bidang PAUD dari Universitas Djuanda Bogor, Helwiyah Makarim, M.Pd., serta mengundang Ketua Himpunan PAUD Indonesia (HIMPAUDI) wilayah Kecamatan Leuwisadeng. Tidak hanya anak-anak yang diajak untuk mengikuti sosialisasi ini, tetapi juga orang tua anak yang berada di sekitar PAUD Al-Hidayah di Kampung Cikadu yang dijadikan sebagai sasaran utamanya. Tujuan khusus dari sosialisasi ini yaitu memberikan pengetahuan kepada masyarakat tentang PAUD dan meningkatkan minat masyarakat terhadap PAUD.

\section{Sosialisasi Wajib Belajar 12 Tahun}

Desa Sadeng Kecamatan Leuwisadeng masih memiliki kampung yang terpencil, hal terlihat dari fasilitas di kampungnya yang masih terbatas. Dengan kondisi keterbatasan tersebut mengakibatkan sebagian besar anak-anak terpaksa putus sekolah dan memilih untuk ikut bekerja bersama dengan orang tua mereka. Sehingga perlu untuk diberikan motivasi agar orang tua dan anak sama-sama memiliki keinginan untuk menggapai jenjang pendidikan yang lebih tinggi, minimal 12 tahun. Motivasi diberikan dalam bentuk sosialisasi. Sosialisasi ini memiliki sasaran yang lebih luas, yaitu masyarakat orang tua peserta didik yang berdomisisli di Desa Sadeng. Kegiatan ini dilaksankana di Gedung Serbaguna Desa Sadeng pada Hari Rabu tanggal 16 Agustus 2017 mulai pukul 09.00 sampai dengan pukul 12.00 WIB. Kegiatan ini berisi sosialisasi oleh para dosen universitas Djuanda. Tujuan khususnya adalah untuk meningkatkan ketertarikan masyarakat terhadap pendidikan formal. Untuk mengefektifkan waktu dalam penyampaian informasi, maka kegiatan sosialisasi wajib belajar 12 tahun ini sekaligus dilaksanakan Penyuluhan Taman Baca Masyarakat (TBM) untuk 
mengoptimalkan program pengadaan taman baca yang telah berjalan terlebih dahulu.

\section{Pengadaan Taman Baca}

Desa Sadeng telah melakukan pengadaan taman baca, kegiatan tersebut dilakukan di posko kegiatan pengabdian di Kampung Cikadu Desa Sadeng. Kegiatan ini menyasar anak-anak usia SD di Desa Sadeng. Kegiatan dilakukan setiap sore hari pada pukul 15.30 sampai dengan 17.00 WIB dengan berbagai macam aktifitas seperti belajar menulis, membaca, berhitung, melipat kertas origami, membacakan cerita dongeng, dan lain-lain. Tujuan khususnya adalah untuk meningkatkan kreatifitas dan kepercayaan diri anak-anak.

\section{Kegiatan Pemberian Bimbingan Belajar}

Kegiatan bimbingan belajar, dilaksanakan di PAUD Al-Hidayah dan SDN Sukajadi. Bimbingan belajar di PAUD Al-Hidayah diselenggarakan setiap Hari Senin dan Kamis mulai pukul 08.00 sampai dengan pukul 10.00 WIB, dan di SDN Sukajadi pada Hari Selasa dan Jumat mulai pukul 07.00 sampai dengan pukul 10.00 WIB. Dalam kegiatan ini peserta didik diberikan pengetahuan dasar menulis, membaca, dan berhitung, serta kegiatan yang melatih motorik peserta didik. Tujuan khusus dari kegiatan ini terletak pada peningkatan pengetahuan peserta didik tentang pola belajar yang baik dan dengan bergaul bersama praktikan maka diharapkan dapat termotivasi untuk melanjutkan pendidikan setinggi-tingginya.

\section{HASIL DAN PEMBAHASAN}

Angka Harapan Lama Sekolah (HSL) dapat ditingkatkan dengan cara memberi dukungan pada bidang pendidikan. Dukungan tersebut berupa pemberian program sosialisasi kepada masyarakat, yaitu sosialisasi minat belajar di PAUD, sosialisasi wajib belajar 12 tahun, pengadaan taman baca, dan kegiatan pemberian bimbingan belajar.

\section{Sosialisasi Minat Belajar di PAUD}

Kegiatan sosialisasi minat belajar di PAUD terlaksana sesuai dengan yang telah direncanakan. Acara dihadiri oleh 45 orang tua siswa dan calon siswa yang berdomisili di Desa Sadeng, sebagian besar peserta berasal dari daerah sekitar PAUD. Acara dapat dimulai tepat waktu yaitu pukul 08.00 WIB. Acara ini diisi dengan berbagai kegiatan, diantaranya adalah: (1) sosialisasi tentang PAUD dan manfaatnya oleh narasumber yang berasal dari Universitas Djuanda Bogor, Helwiyah Makarin, M.Pd.; (2) pemberian doorprise bagi anak-anak untuk menambah semangat; dan diakhiri dengan (3) menari bersama panitia dengan gerakan yang mudah dilakukan. Masyarakat yang pada awalnya merasa malu-malu pada akhirnya dapat membaur bersama dengan panitia. Hal ini menunjukkan bahwa masyarakat mulai bisa menerima keberadaan PAUD sebagai jembatan bagi anak-anak mereka untuk belajar sebelum masuk ke jenjang sekolah dasar.

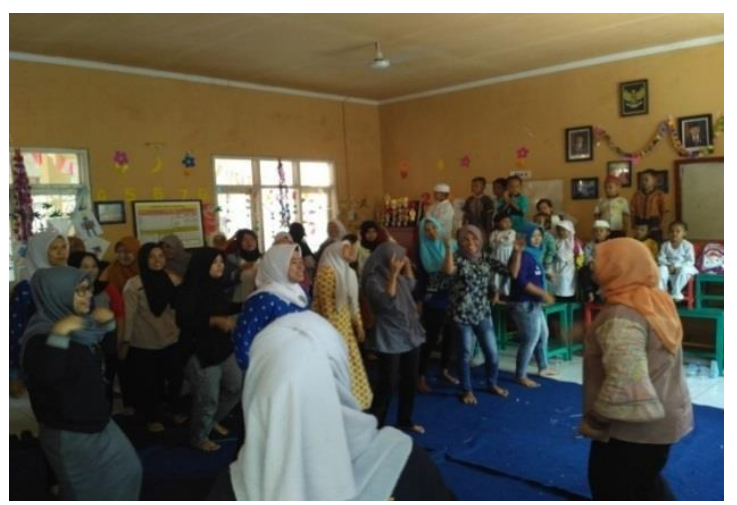

Gambar 2 Kegiatan sosialisasi minat belajar di PAUD yang diselenggarakan di PAUD Al-Hidayah

\section{Sosialisasi Wajib Belajar 12 Tahun}

Kegiatan ini menjadi kegiatan utama dalam serangkaian program sosialisasi pendidikan di Desa Sadeng. Masyarakat diberi pengetahuan tentang pentingnya pendidikan tinggi di jaman modern ini supaya tidak tertinggal dan dapat bersaing dengan masyarakat di daerah lain. Acara ini dihadiri oleh perwakilan masyarakat yang berasal dari semua kampung yang ada di 
Desa Sadeng. Jumlah peserta yang hadir 78 orang yang tertampung semua dalam gedung serbaguna Desa Sadeng.

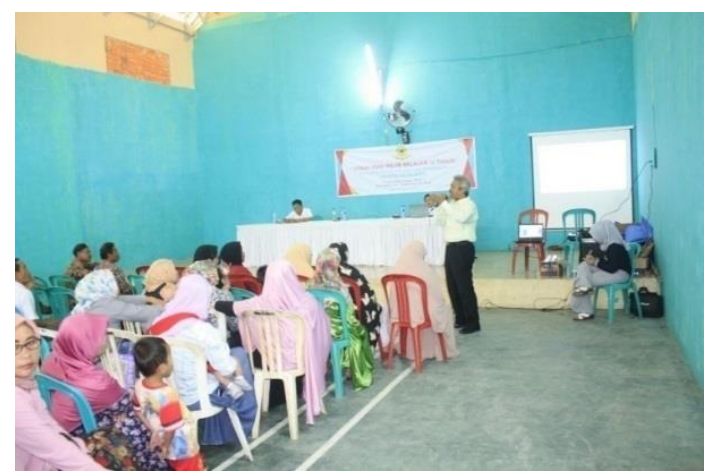

Gambar 3 Kegiatan sosialisasi wajib belajar 12 tahun

\section{Pengadaan Taman Baca}

Teknis pengadaan taman baca di Desa Sadeng terlaksana melalui tahapan sebagai berikut: (1) mencari tempat yang setrategis dimana masyarakat dapat melakukan kegiatan membaca dengan nyaman, sehingga kegiatan yang awalnya dilaksanakan di posko pengabdian kemudian dipindah ke ruang kelas PAUD AlHidayah. Pemilihan lokasi taman baca ditentukan dengan mempertimbangkan agar taman baca tersebut dapat dilanjutkan setelah kegiatan pengabdian berakhir; (2) penyediaan buku diperoleh dari sumbangan Perpustakaan Nasional yang diberikan kepada Pemerintah Desa Sadeng tahun sebelumnya yang programnya belum sempat terealisasi; (3) penyediaan sarana dan prasarana dengan pembuatan dua rak buku yang terbuat dari bahan kayu yang dicat; dan (4) penyediaan pengelola diperoleh dari hasil kerjasama dengan pemuda-pemudi karang taruna Desa Sadeng yang bersedia untuk mengelola dan memanfaatkan buku-bukunya untuk perpustakaan keliling, sehingga masyarakat yang rumahnya jauh dari lokasi taman baca bisa ikut membaca buku-bukunya juga.

Masyarakat merespon dengan sangat antusias. Pengunjung taman baca sebagian besar adalah anak-anak yang berada dalam usia belajar membaca, dan beberapa orang tua yang ikut mendampingi anak mereka.
Selain itu tujuan dari taman baca ini juga sebagai bagian dari tinjak lanjut dari program taman baca yang diadakan di posko pengabdian sebelumnya, juga sebagai penyemangat dan sarana penumbuh budaya gemar membaca bagi seluruh warga Desa Sadeng.

Adapun output kegiatan taman baca ini sebagai berikut: (1) sarana belajar masyarakat untuk belajar mandiri, sekaligus penunjang kurikulum program Pendidikan Luar Sekolah; (2) informasi yang diambil dari sumber buku dan bahan bacaan lainnya sesuai kebutuhan belajar masyarakat setempat; (3) sumber penelitian dengan menyedikan buku - buku dan bahan bacaan lainnya dalam studi kepustakaan; (4) sumber rujukan sebagai bahan referensi bagi kegiatan pembelajaran dan akademik lainnya; (5) sumber hiburan penyedia bahan bacaan untuk memperoleh pengetahuan atau informasi baru yang bermanfaat di waktu luang.

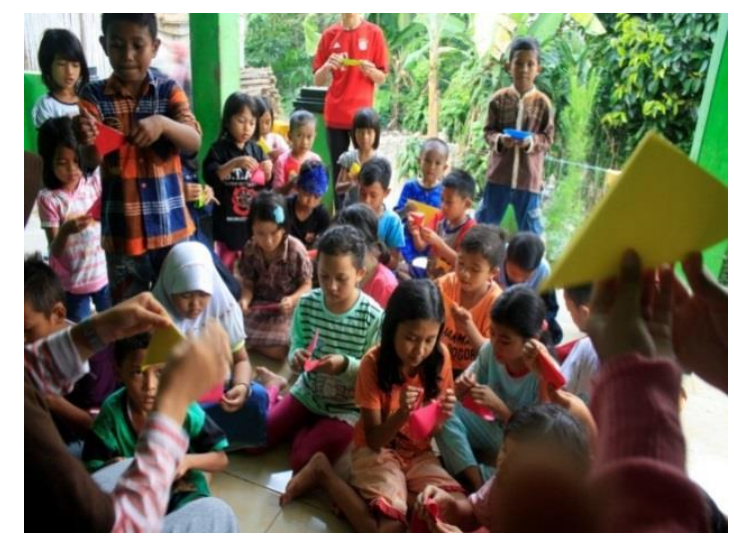

Gambar 4 Kegiatan peningkatan kreativitas anak di taman baca

\section{Kegiatan Pemberian Bimbingan Belajar}

Kegiatan ini difokuskan hanya pada anak sekolah dini dan anak usia sekolah dasar. Teknis pelaksanaannya dilakukan dengan melakukan kegiatan pembelajaran bersama dengan praktikan, supaya anak-anak terbiasa dan tidak canggung berinteraksi dengan masyarakat dari luar daerah, sehingga termotivasi untuk meraih pendidikan setinggi-tingginya, bahkan 
mereka mulai memiliki gambaran dan dapat menceritakan tentang cita-cita ketika dewasa kelak. Kegiatan ini memiliki keterbatasan waktu, yaitu selama 40 hari atau selama praktikan masih melakukan kegiatan pengabdian di Desa Sadeng.

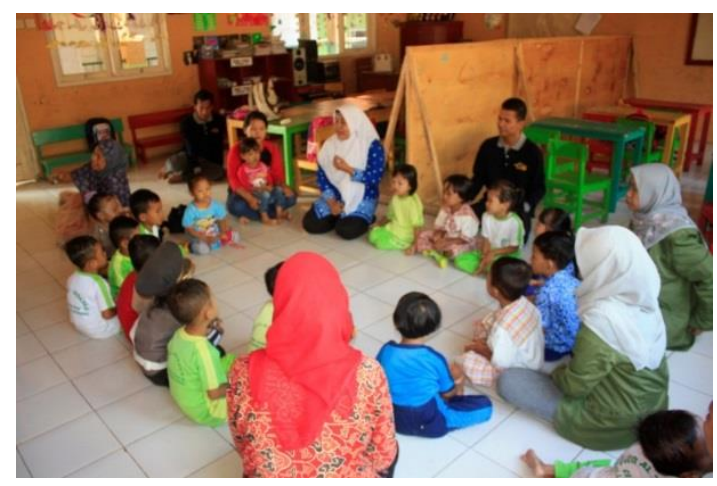

Gambar 5 Pemberian bimbingan belajar

\section{Kegiatan Pemberdayaan Masyarakat Lainnya}

Kegiatan pengabdian ini juga memiliki kegiatan tambahan guna meningkatkan aktivitas yang bermanfaat bagi masyarakat, yaitu dilakukanya program Jumat Bersih. Kegiatan ini dilakukan setiap Hari Jumat oleh anggota tim pengabdian dan masyarakat sekitar. Tujuan dari kegiatan ini adalah untuk mempererat silaturahmi dan keakraban antara tim pengabdian yang terdiri dari mahasiswa dan masyarakat sekitar, serta menumbuhkan rasa suka akan kebersihan lingkungan.

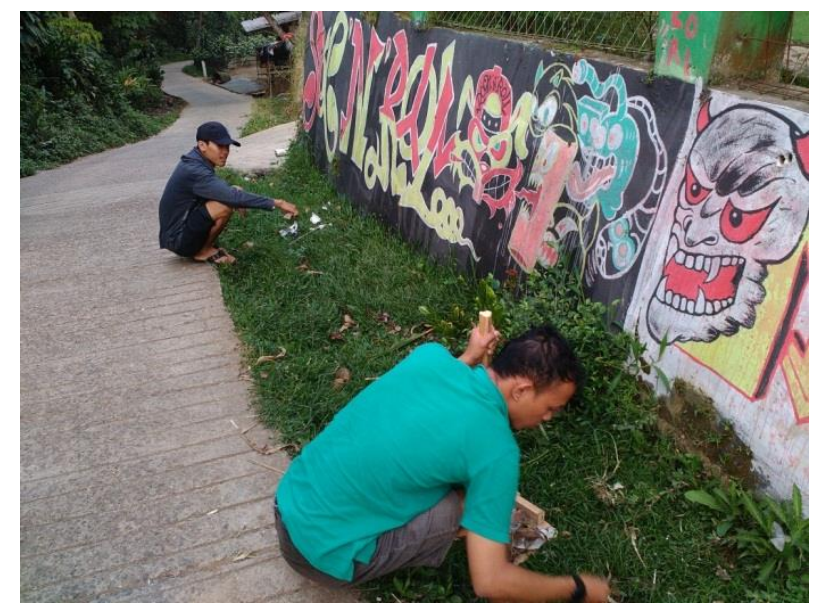

Gambar 6 Kegiatan Jumat bersih

Program lain di bidang kesehatan adalah dengan mengadakan senam rutin Hari
Minggu pagi yang dilaksanakan di lapangan Kampung Cikadu bersama anak-anak dan warga Kampung Cikadu. Bersenam diharapkan dapat menumbuhkan semangat para warga untuk beraktivitas. Kegiatan senam ini sangat ditunggu oleh warga karena menurut mereka kegiatan ini cukup menyenangkan.

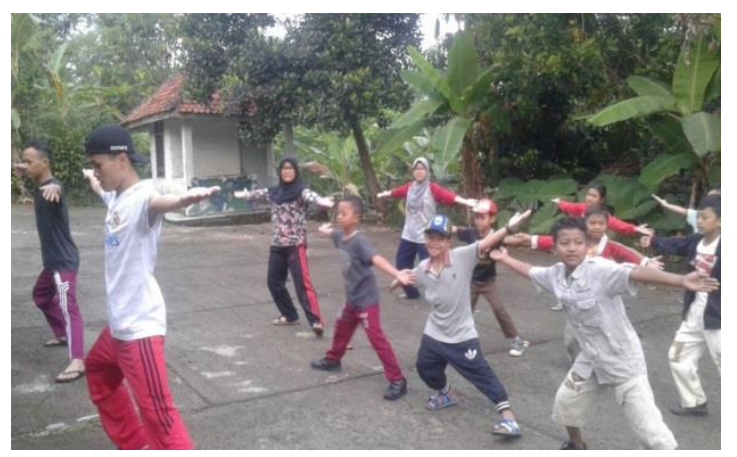

Gambar 7 Kegiatan senam bersama

Kegiatan selanjutnya yaitu ikut membantu program posyandu yang dilakukan setiap sebulan sekali. Kegiatan ini merupakan kegiatan rutinitas yang biasa dilaksanakan pada minggu pertama setiap bulannya. Rangkaian kegiatannya diantaranya penimbangan berat badan, tinggi badan balita, imunisasi pemeriksaan balita, dan pemeriksaan pada ibu hamil, serta membantu merapihkan buku administrasi. Selain itu tim kegiatan pengabdian juga mengikuti penyuluhan campak dan Rubella yang dilaksanakan di puskesmas Kecamatan Leuwisadeng, program ini bermanfaat dalam membantu masyarakat mengenal betapa pentingnya melakukan vaksin campak dan Rubella serta menghimbau kepada masyarakat sekitar untuk selalu mengikuti posyandu bulanan agar tumbuh kembang anak-anak bisa di kontrol. Adapun penyuluhan ini sangat di dukung penuh oleh semua pihak dari pemerintah maupun masyarakat.

Salah satu kegiatan di bidang sosial adalah gotong royong. Gotong royong dilakukan sebagai upaya membantu masyarakat merenovasi masjid. Seluruh mahasiswa tim pengabdian terjun langsung untuk kegiatan ini. Seluruh tim membantu semaksimal mungkin mulai dari membantu 
dalam bentuk tenaga maupun materi. Tim pengabdian merasa kagum kepada masyarakat sekitar karena kekompakan yang ditunjukkan oleh masyarakat. Berdasarkan hasil pengamatan, masyarakat di Kampung Cikadu masih memegang teguh sikap solidaritas yang sangat tinggi, bisa dilihat dari banyaknya masyarakat yang ikut serta tanpa memandang tua-muda, kayamiskin, perempuan-laki-laki semuanya berbaur menjadi satu.

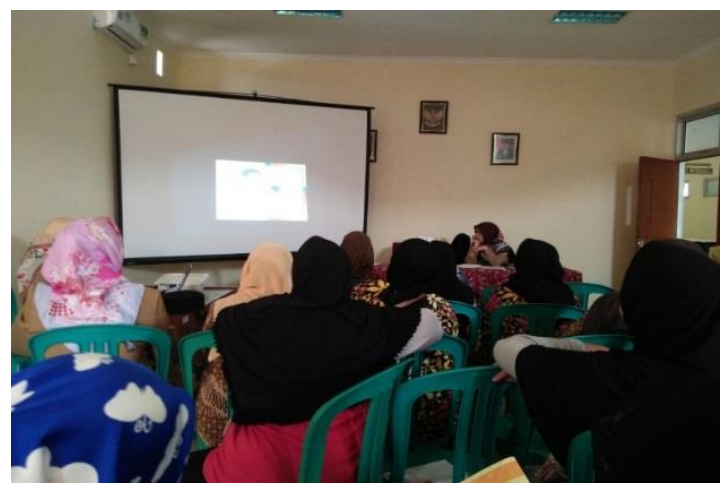

Gambar 8 Penyuluhan campak dan rubella

Kegiatan gotong royong juga dilaksanakan dalam pembangunan Masjid Baitul Muttaqin dan dilaksanakan setiap hari dengan pembagian tugas dari setiap masing-masing RT berpartisipasi minimal 3 orang warga setiap harinya, sampai renovasi ini selesai. Dalam konteks ini peran masyarakat sangat dibutuhkan, baik dalam bentuk tenaga maupun materi. Kegiatan yang dilakukan seperti, membawa pasir, membawa split dan sebagainya. Kegiatan ini dilakukan karena lokasi bahan bangunan jaraknya cukup jauh dari masjid. Kegiatan ini dilakukan biasanya saat hari libur, atau saat barang bangunan datang. Tujuan kegiatan ini untuk memupuk rasa solidaritas antar warga, dan membuat pekerjaan terasa lebih ringan.

Selain kegiatan gotong royong, dengan adanya renovasi mesjid di kampung Cikadu, tim pengabdian berinisiatif untuk membantu penggalangan dana untuk pembangunan mesjid Baitul Muttaqin. Penggalangan tersebut dilakukan melalui penjualan kupon. Kupon disini dilatarbelakangi karena adanya renovasi
Masjid Jami' Baitul Muttaqin, dan masyarakat di sana juga meminta bantuan kepada mahasiswa guna melancarkan pembangunan masjidnya. Atas dasar itu mahasiswa berinisiatif membuat kupon yang bisa ditukarkan dengan uang. Kupon dibuat dengan nominal yang bermacammacam terdiri dari kupon Rp 2000,00, Rp 5000,00, Rp 10.000,00, dan Rp 20.000,00. Kupon itu pun dijual dan disebarkan keseluruh masyarakat yang ada di Desa Sadeng, tidak hanya Desa Sadeng tetapi penjualan kupon dilakukan di tempat lain seperti di toko-toko, sekolah, sampai pasar. Kegiatan ini dilaksanakan setiap hari. Dan dana yang terkumpul dari penjualan kupon yaitu Rp 2.600.000,00, sudah termasuk yang berinfaq melalui penyebaran proposal Masjid Baitul Muttaqin untuk pembangunan masjid.

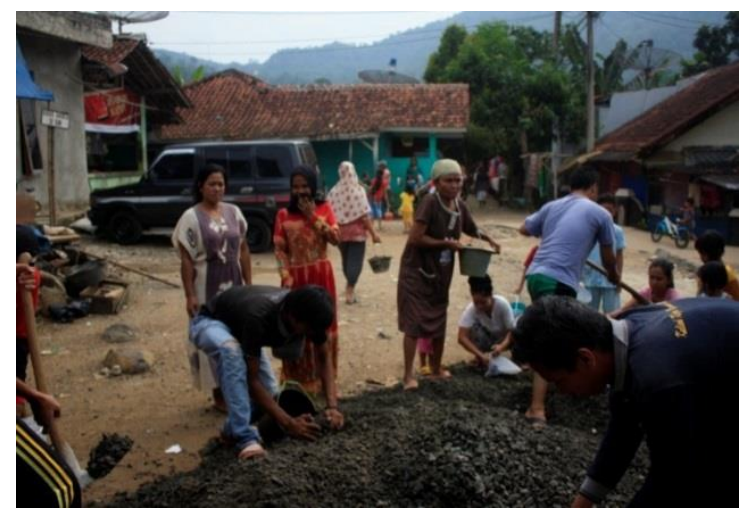

Gambar 9 Kegiaan gotong royong pembangunan masjid

Kegiatan sosial yang lainnya adalah membuat sebuah papan petunjuk arah. Kegiatan ini dilatarbelakangi dengan tidak adanya papan penunjuk lokasi. Atas dasar itu tim pengabdian berinisiatif membuat plang untuk digunakan sebagai penunjuk jalan. Kegiatan ini diawali pembelian besi kemudian pengelasan, dilanjut dengan pengecatan dan pemberian keterangan sesuai dengan kebutuhan. Hasil yang diperoleh dari pengadaan plang ini adalah, dapat membantu masyarakat mengenali arah suatu daerah, jalan atau ruang publik lainnya. Papan petunjuk arah ini dipasang di 5 titik untuk mempermudah akses menuju Kampung Cikadu. Tujuan dari kegiatan ini 
adalah membantu masyarakat mengenali arah menuju Kampung Cikadu, karena ada beberapa persimpangan dan Kampung Cikadu memang cukup dikenal karena duriannya yang memiliki kualitas unggul.

Dalam rangka memperingati HUT RI yang ke-72 Kecamatan Leuwisadeng mengadakan acara yang berkenaan dengan kemerdekaan. Acara tersebut antara lain yaitu gerak jalan dan jalan santai. Gerak Jalan diselenggarakan oleh pihak Kecamatan Leuwisadeng pada Hari Sabtu tanggal 12 Agustus 2017. Start dilakukan dari lapangan Paku Landeuh sampai ke halaman Kecamatan Leuwisadeng. Kegiatan ini diikuti oleh peserta dari PAUD, SD/MI, SMP/MTs, SMA dan Umum. Antusias warga terlihat saat mengikuti gerak jalan hingga jumlahnya dapat memenuhi lapangan Kecamatan Leuwisadeng. Atas permintaan panitia gerak jalan, tim pengabdian diikutsertakan sebagai juri pada acara tersebut.

Selanjutnya pada tanggal 17 Agustus 2017 diadakan upacara HUT RI ke-72 di lapangan kantor Desa Sadeng. Upacara ini dihadiri seluruh warga Desa Sadeng. Pelaksanaan upacara ini berlangsung secara khitmat yang dipimpin oleh Kepala Desa Sadeng. Hasil yang diperoleh dari kegiatan Upacara Kemerdekaan HUT RI Ke 72 ini adalah: (1) meningkatkan nasionalisme tim pengabdian dan masyarakat,

mengingatkan kewajiban masyarakat sebagai penerus bangsa tentang perjuangan para pahlawan dalam merebut kemerdekaan. Untuk menambah kemeriahan HUT RI serta mempererat tali persaudaraan antar warga, berbagai perlombaan pun dilaksanakan di setiap kampung, salah satunya Kampung Cikadu. Pelombaan ini diselenggarakan 2 hari yaitu pada tanggal 16-17 Agustus 2017 antara lain yaitu lomba bakiak kahirupan, kerupuk bunuh diri, pocong setengah awak, moto gp, jeruk geboy, sendok kelereng, dan sebagainya.

Tim pengabdian sangat termotivasi dengan adanya kegiatan di Desa Sadeng yang sangat antusias memeriahkan acara tersebut, apalagi dengan adanya Karang Taruna yang sangat membantu dalam kegiatan di Desa Sadeng. Bidang Kerohanian. Kampung Cikadu merupakan salah satu kampung yang cukup kental dari segi kerohaniannya. Salah satu bentuknya ialah dengan adanya pengajian yang dilakukan secara rutin dari berbagai kalangan mulai dari anak-anak, ibu-ibu hingga bapak-bapak. Tim pengabdian juga mengikuti pengajian tersebut. Selain untuk meningkatkan keimanan, acara ini juga dapat meningkatkan sosalisasi antar warga sekitar. Selain itu, Baca Tulis Al-Quran (BTQ) merupakan salah satu kegiatan yang dilakukan setiap malam Jum'at, setelah adzan magrib dan diikuti oleh anak-anak. Untuk menambah minat anak-anak baca tulis Al-Quran maka diberikan materi semenarik mungkin seperti hafalan dalam bentuk permainan.

Selanjutnya setiap malam Senin dan Rabu secara rutin diadakan kegiatan pengajian yang dilaksanakan oleh bapak-bapak, pengajian ini pun diikuti oleh masyarakat yang ada di Kampung Cikadu. Antusias bapak-bapak yang mengikuti kegiatan ini sangat tinggi sehingga lokasi kegiatan yaitu mushola selalu penuh. Setiap warga memiliki tugas masing-masing dalam kegiatan ini diantaranya bagian konsumsi, bagian teknisi, dan pengisi acara. Kegiatan serupa tidak hanya diadakan oleh bapakbapak, ibu-ibupun mengadakan pengajian yang dilaksanakan setiap Hari Jumat pagi dan diikuti oleh remaja pengajian dilaksanakan jam 6 pagi hingga selesai.

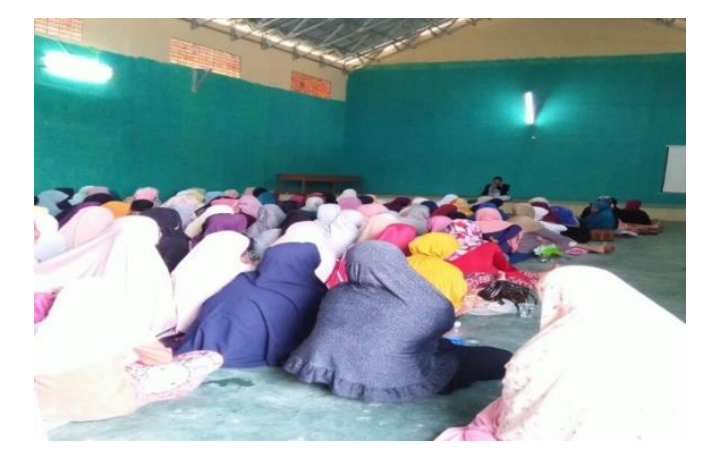

Gambar 10 Kegiatan Pengajian 


\section{KESIMPULAN DAN IMPLIKASI}

\section{Kesimpulan}

Kegiatan pengabdian ini dilaksanakan di Desa Sadeng. Kegiatannya antara lain (1) sosialisasi minat belajar di PAUD yang dilaksanakan di PAUD Al-Hidayah berjalan sesuai dengan rencana dan dihadiri oleh orang tua dan anak-anak usia dini yang berjumlah 45 orang, (2) sosialisasi wajib belajar 12 tahun di gedung serbaguna Desa Sadeng dapat menarik antusias 78 masyarakat Desa Sadeng, (3) pengadaan taman baca dapat terselenggara di ruang kelas PAUD Al-Hidayah dan dikelola oleh pemuda-pemudi karang taruna Desa Sadeng, dan (4) pemberian bimbingan belajar dapat terlaksana selama 40 hari di PAUD Al-Hidayah dan SDN Sukajadi. Implikasi.

Kegiatan pengabdian ini telah memberikan perubahan dan pemberdayaan masyarakat yang dilakukan di setiap kegiatan khususnya dari bidang Pendidikan dan sosial untuk meningkatkannya kualitas mutu pendidikan Desa Sadeng. Untuk kelancaran dan kelanjutan program yang telah dilaksanakan diperlukan kerjasama antara lembaga pemerintah dan masyarakat. Terutama dalam perawatan, dan kesadaran masyarakat akan programprogram yang telah terlaksana dan di tindak lanjuti. Dari penelitian yang di temukan bahwa terdapat perbedaan yang signifikan antara adanya kehadiran dan sebelum adanya mahasiswa di lingkungan masyarakat dengan beberapa programprogram yang sudah terlaksana.

\section{Implikasi}

Mahasiswa Universitas Djuanda memberi pengaruh terhadap pembangunan fisik dan pengetahuan di bidang pendidikan khususnya di acara sosialisasi yang telah dilaksanakan. Terutama pada acara sosialisasi PAUD dan Wajib Belajar 12 Tahun. Sosialisasi memberikan pengaruh yang baik akan perkembangan masyarakat Desa Sadeng. Lewat sesi tanya jawab, para tokoh masyarakat sedikitnya dapat memahami cara mengatasi warganya yang kurang berminat menyekolahkan anaknya ke jenjang yang lebih tinggi. oleh sebab itu apabila pemerintah akan meningkatkan pendidikan di setiap masyarakatnya, salah satu cara yang harus diakukan adalah sosialisasi atau penyuluhan. Sementara itu untuk masyarakat yang kurang mengerti akan cara meningkatkan kesadaran warga. Masyarakat bisa bertanya ke orang yang lebih mengerti tentang pendidikan. Hasil yang diperoleh dari kegiatan sosialisasi ini sangat mendukung kebijakan pemerintah, dalam rangka meningkatkan mutu pendidikan.

\section{UCAPAN TERIMA KASIH}

Ucapan terimakasih kepada Universitas Djuanda Bogor dan BAPPEDA Kabupaten Bogor yang telah memfasilitasi segala perijinan dan mendukung penuh untuk kegiatan pengabdian ini. Ucapan terima kasih ini juga disampaikan kepada Bapak $\mathrm{H}$. Asep Saepul Anwar selaku Kepala Desa Sadeng beserta jajarannya dan Karang Taruna Desa Sadeng yang telah memberikan ijin dan mendukung penuh kegiatan pengabdian selama 40 hari. Ucapakan terima kasih juga untuk semua donatur yang telah membantu dan mendukung kegiatan di Desa Sadeng.

\section{DAFTAR PUSTAKA}

BPS. (2016). Indeks Pembangunan Manusia. Retrieved from www.bps.go.id.

BPS Jabar. (2015, November 19). Indeks Pembangunan Manusia Metoda Baru Provinsi Jawa Barat dan KAbupaten/Kota Tahun 2010-2014. Retrieved from www.bps.go.id.

Handayani, N. S., Bendesa, I., \& Yuliarmi, N. (2016). Pengaruh Jumlah Penduduk, Angka Harapan Hidup, Rata-Rata Lama Sekolah, dan PDRB Per Kapita Terhadap Pertumbuhan Ekonomi di Provinsi Bali. Jurnal Ekonomi dan Bisnis Universitas Udayana, 5(10), 3449-3474. 
Hasan, M. (2012). Pendidikan Anak Usia Dini. Yogyakarta: Diva Press.

Kun, M. (2005). Sosiologi 1. Jakarta: Esis.

Mudyahardjo, R. (2002). Pengantar Pendidikan. Jakarta: PT Raja Grafindo.

Narwoko, D., \& Suyanto, B. (2006). Sosiologi Teks Pengantar dan Terapan. Jakarta: Kencana.

Nofijantie, L. (2014, Januari). Peran Lembaga Pendidikan Formal sebagai Modal Utama Membangun Karakter Siswa. Jurnal Ilmu Tarbiyah "At-Tajdid", 3(1), 45-71.

Oemar, H. (2005). Perencanaan Pengajaran Berdasarkan Pendekatan Sistem. Jakarta: Bumi Aksara.

Republik Indonesia. (2003). Undang-Undang Nomor 20 Tahun 2003 tentang Sisdiknas. Jakarta: Kementrian Pendidikan Nasional.

Santrock, J. W. (2014). Psikologi Pendidikan (5 ed.). Jakarta: Salemba Humanika.

Soegeng, S. (2006, Desember). Optimalisasi Tumbuh Kembang Anak Usia Dini Menuju
Anak yang Sehat dan Cerdas Melalui Permainan. Jurnal Pendidikan Penabur, 5(7), 93-99.

Sulisetyowati, A. (2016). Dukungan Pendidikan Anak Usia Dini (PAUD) Terhadap Tumbuh Kembang Anak. Jurnal Ilmu Kebidanan, 2(2), 71-78.

Tilaar. (1999). Pendidikan Kebudayaan, dan Masyarakat Madani Indonesia. Bandung: PT Remaja Rosdakarya.

Ulfatin, N., Mukhadis, A., \& Imron, A. (2010, Februari). Profil Wajib Belajar 9 Tahun dan Alternatif Penuntasannya. Jurnal Ilmu Pendidikan, 17(1), 36-45.

Wardani, W. K. (2013). Implementasi Program Wajib Belajar 12 Tahun di Provinsi DKI Jakarta (Studi Kota Administrasi Jakarta Timur). Semarang: Universitas Diponegoro. 